\title{
OSMOREGULASI PADA HEWAN AKUATIK
}

\author{
Sartje Lantu \\ Staf Pengajar pada Program Studi Budidaya Perairan, \\ Fakultas Perikanan dan IImu Kelautan. UNSRAT. Manado 95115.
}

\author{
ABSTRACT \\ Lantu, S., 2010. Osmoregulation in Aquatic Animals. \\ Jurnal Perikanan dan Kelautan. Vol VI (1): 46-50.
}

\begin{abstract}
All aquatic organisms must deal with the problem of maintaining internal homeostasis, a constant internal chemical environment in which that organism's enzymes can operate efficiently. As we saw earlier, this is largely a matter of osmoregulation, but other factors are involved also. Many marine organisms can get by with minimal osmoregulation since the oceans, where the enzymes evolved, are already a good environment; other marine organisms maintain their body fluids at ionic concentrations different from the surrounding ocean and must actively regulate ions. Freshwater also calls for active measures to maintain proper osmotic balance.
\end{abstract}

Keywords: homeostasis, osmoregulasi, organisme akuatik.

\section{PENDAHULUAN}

Salinitas menjadi faktor pembatas bagi kehidupan hewan akuatik (Anonim, 1999). Osmoregulasi terjadi pada hewan perairan, karena adanya perbedaan tekanan osmosis (osmosis berasal dari bahasa Junani yang berarti mendorong) antara larutan (biasanya kandungan garam-garam) di dalam tubuh dan di luar tubuh. Sehingga osmoregulasi merupakan upaya hewan air untuk mengontrol keseimbangan air dan ion-ion yang terdapat di dalam tubuhnya dengan lingkungan melalui sel permeable (Nicol, 1967). Pengaturan osmoregulasi ini sangat mempengaruhi metabolisme tubuh hewan perairan dalam menghasilkan energi (Ricklefs, 1997).

Regulasi ion dan air pada hewan akuatik dapat terjadi secara hipertonik (hiperosmotik), hipotonik (hipoosmotik) atau isotonik (isoosmotik) (Gambar 1). Bagi golongan ikan potadromous yang bersifat hiperosmotik, air bergerak ke dalam dan ion-ion keluar ke lingkungan perairan melalui cara difusi. Keseimbangan cairan tubuhnya terjadi melalui cara dengan sedikit meminum air bahkan tidak minum air sama sekali. Apabila terdapat kelebihan air dalam tubuh, maka air ini dikeluarkan melalui urine. Bagi golongan ikan oseanodromous yang bersifat hipoosmotik terhadap lingkungannya,

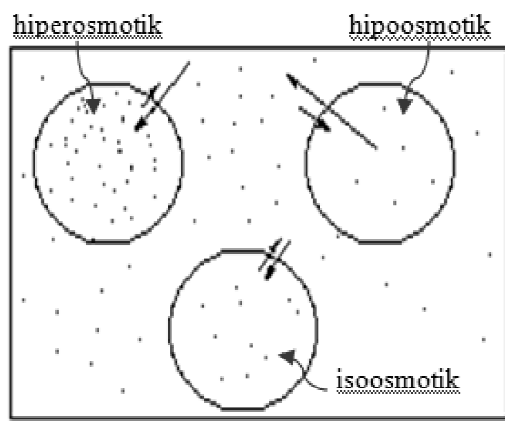

Gambar 1. Regulasi ion pada hewan akuatik air mengalir secara osmosis dari dalam tubuhnya melalui ginjal, insang dan kulit ke lingkungan; sedangkan ion-ion masuk ke dalam tubuhnya secara difusi. Bagi golongan ikan eurihalin, maka pengaturan ion dilakukan secara isoosmotik. Kebanyakan hewan akuatik laut baik invertebrata maupun vertebrata termasuk ke dalam golongan isoosmotik.

Namun demikian terdapat spesis dari golongan mysid dan amphypoda yang memiliki toleransi yang demikian luas untuk temperatur dan salinitas, berkisar dari perairan pantai sampai daerah estuari. Beberapa bahkan dapat mencapai perairan 
tawar dan melakukan reproduksi (Lockwood 1976; Wittmann and Ariani 2000; Bruijs et al. 2001;Santagata et al., 2008).

\section{OSMOREGULASI PADA IKAN}

Karnaky Jr. and Karl, J. (1998) menyatakan bahwa golongan ikan menghadapi tantangan yang sulit dalam mempertahankan kandungan garam dalam tubuh karena mereka hidup di lingkungan perairan dan mempunyai tendensi untuk melepaskan air sebanyak mungkin. Konsentrasi garam pada tubuh ikan air tawar lebih tinggi dibandingkan lingkungannya, sehingga kandungan garam lebih sering dikeluarkan ke perairan. Untuk mengatasi hal ini, ikan mempunyai beberapa cara, diantaranya mereka akan mengkonsumsi sejumlah air yang banyak dan sebagai konsekuensinya akan memproduksi sejumlah besar urine (10-20 kali sama seperti hewan mamalia di darat). Ginjal dari golongan ikan ini menyerap sejumlah garam dan melepaskan garam tersebut ke aliran darah. Cara yang lain adalah golongan ikan ini memiliki pompa ion di bagian ginjal yang akan menangkap garam dari air serta melepaskan amonia dan hasil buangan lainnya.

Ikan air laut memiliki masalah yang sama tapi kebalikannya. Untuk ikan air laut, air laut mengandung konsentrasi garam yang lebih tinggi dibandingkan dengan kandungan garam yang ada di tubuh ikan. Sebagai hasilnya, garam cenderung masuk ke tubuh ikan sehingga ikan harus menggunakan ginjalnya serta pompa ionnya untuk mengeluarkan kelebihan garam. Proses osmoregulasi pada ikan air tawar dan ikan air laut dapat dilihat pada Gambar 2.

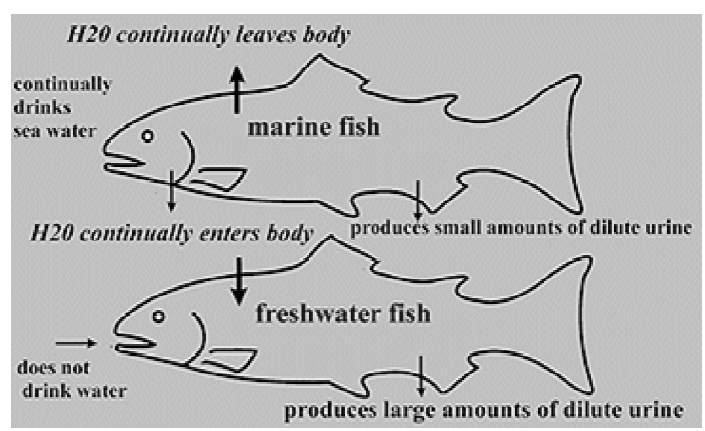

Gambar 2. Proses osmoregulasi pada ikan air tawar dan ikan air laut

Golongan ikan hagfish adalah

isotonic terhadap air laut dan tidak mengatur air. Golongan ini mengatur garamgaram. Pada golongan elasmobranch memiliki konsentrasi garam seperti pada vertebrata lainnya (hampir mencapai sepertiga bagian air laut). Namun demikian cairan tubuhnya hampir mendekati isotonik (sedikit isotonik) terhadap air laut. Tekanan osmotik cairan tubuh lainnya adalah disebabkan oleh adanya urea dan trimetilamin (TMAO). Golongan ini sering menyerap air yang digunakan untuk eksresi. Kelebihan garam yang masuk ke dalam tubuh akan dihilangkan melalui kelenjar khusus yang menggunakan pompa $\mathrm{Na}+$ melewati bagian rectum.

Golongan ikan teleos laut memiliki cairan tubuh kira-kira $1 / 3$ dari tekanan osmotik air laut. Golongan ini akan minum air laut dan menyerapnya ke dalam tubuh. Dengan pompa $\mathrm{Na}^{+}$dari sel klorida dalam insang, $\mathrm{Na}^{+}$akan dipompa ke laut. Amonia juga akan dilepaskan melalui insang, sisa ion akan dikeluarkan melalui ginjal. Pada ikan pipe fish serta kuda laut, mereka memiliki ginjal aglomerular dan tidak menyaring darah di ginjal. Semua ekresi dilakukan oleh pompa seluler serta difusi.

\section{OSMOREGULASI PADA GOLONGAN KRUSTASEA/KEPITING}

Untuk golongan kepiting (Brachyura), beberapa spesis (contohnya Callinectes sapidus, blue crab) memiliki kemampuan untuk melakukan osmoregulasi dan berhasil hidup di air tawar. Golongan yang lain (contohnya Carcinus maenas, kepiting yang hidup di pantai) mempunyai toleransi yang kecil untuk air tawar tetapi mempertahankan konsentrasi ion yang tinggi di perairan estuari. Beberapa yang lain (seperti Callinectes similis) kurang memiliki kemampuan dalam mengatur 
osmoregulasi pada kisaran tersebut di atas. Kisaran dari kemampuan dalam mengatur osmoregulasi pada golongan krustasea sering dipakai dalam pendekatan fisiologi untuk mengidentifikasi kemampuan gen yanag spesifik yang berkontribusi dalam pengaturan osmoregulasi.

Organ yang mana yang paling berperan dalam pengaturan osmoregulasi bagi golongan krustasea? Kelenjar pada antena dari golongan kepiting tidak mempunyai kemampuan untuk memproduksi urine sehingga tidak dapat dikatakan sebagai organ yang penting dalam pengaturan osmoregulasi. Hepatopankreas dari golongan krustasea menggambarkan alat transport untuk berbagai kondisi namun hal ini belum dipelajari secara komprehensif. Meskipun intestin krustasea telah diketahui sebagai organ yang dapat membawa ion-ion dan kelihatannya merupakan komponen utama dalam menyerap air, namun kontribusi dari organ ini untuk pengaturan osmoregulasi kelihatannya kurang.

Studi menunjukkan bahwa insang untuk golongan eurihalin krustasea berperan sebagai organ utama dalam pengaturan ion untuk proses osmoregulasi (Gross et al., 1966). Meskipun terdapat variasi secara morfologi, insang serta bagian-bagiannya memiliki bentuk sel yang menggambarkan kemampuan untuk transpor ion-ion. Karakteristik yang khusus dari sel epithelial dilengkapi dengan bentuk permukaan membran, terutama di bagian basolateral yang bersentuhan langsung dengan cairan. Mitokondria dari sel-sel ini menyediakan ATP serta fosfagen yang menjadi energy untuk proses transpor ion. Sel epithelial insang yang berfungsi dalam pertukaran gas bentuknya lebih tipis.

Studi juga menunjukkan bahwa insang, lamela insang dan membran menggambarkan pola yang bervariasi dalam pengaturan transpor ion untuk golongan eurihalin krustasea (Pequeux, 1995). Ada terdapat asumsi bahwa tenaga utama yang mengatur transpor ion melalui insang dilakukan oleh pompa sodium atau enzim $\mathrm{Na}^{+}+\mathrm{K}^{+}-\mathrm{ATPase}$. Pompa kedua yang menggunakan ATP yang juga berperan penting dalam penyerapan ion sehingga organisme dapat dengan sukses bertoleransi dengan air tawar adalah enzim $\mathrm{H}^{+}$-ATPase tipe $\mathrm{V}$ (contohnya Eriocheir sinensis, Chinese crab).

Dua macam enzim yang membantu transport ion melewati insang krustasea adalah karbonat anhidrase dan arginin kinase. Karbonat anhidrase menyediakan ion $\mathrm{H}^{+}$dan $\mathrm{HCO}_{3}{ }^{-}$sebagai lawan ion $\mathrm{Na}^{+}$dan $\mathrm{Cl}^{-}$untuk pertukaran dengan mengkatalisis hidrasi $\mathrm{CO}_{2}$ di dalam sel insang. Aktifitas dari karbonat anhidrase dalam sitoplasma insang akan bertambah secara drastis ketika kepiting berpindah dari tempat yang bersalinitas tinggi ke tempat yang bersalinitas rendah, dimana fungsinya menyediakan ion yang akan melawan ion $\mathrm{NaCl}$ pada saat penyerapan. Proses penggunaan ATP dalam rangka transpor ion tergantung pada kerja enzim arginin kinase. Kepiting yang berpindah dari salinitas yang tinggi ke salinitas rendah, akan menyebabkan aktifitas enzim arginin kinase bertambah kelipatan dua dalam insang.

\section{OSMOREGULASI PADA GOLONGAN MOLUSKA}

Osmoregulasi pada moluska penting untuk mempertahankan kesimbangan kandungan air dan garam melalui penyerapan dan pembuangan. Hal ini penting untuk spesis moluska yang hidup pada berbagai keadaan lingkungan yaitu dari air laut ke daerah air tawar. Ketika salah satu atau secara kelompok bermigrasi atau pindah maka pengaturan osmoregulasi terjadi ketika pindah ke lingkungan yang baru.

Pertahanan akan keseimbangan air dalam tubuh moluska penting untuk fungsi membran sel. Kebanyakan invertebrata laut termasuk spesis moluska seperti kerang-kerangan, siput, tiram dan lain-lain adalah isoosmotik. Hal ini berarti spesis moluska memiliki tekanan osmotik yang sama dan cairan mengalir melalui membran dengan larutan berkonsentrasi rendah ke daerah yang memiliki larutan yang 
berkonsentrasi tinggi. Ketika kelompok moluska bermigrasi tidak terjadi masalah terhadap pengaturan osmoregulasi dan mereka dapat mendiami dan mempertahankan stabilitasnya di lingkungan mereka yang baru (Russell, 2000).

Tidak semua spesis moluska dapat melakukan hal seperti di atas. Moluska di daerah mangrove tidak dapat beradaptasi secara mudah di lingkungan yang baru. Pengaturan osmoregulasi moluska adalah teknik adaptasi yang khusus yang akan membuat mereka bertahan pada lingkungan yang baru, dimana terdapat ketimbangan dalam jumlah air untuk mempertahankan cairan tubuh mereka dimanapun mereka hidup, hal ini disebut sebagai osmoregulator. Invetebrata dari perairan tawar adalah termasuk ke dalam osmoregulator. Organ yang menyerupai ginjal pada organisme invertebrata melakukan pekerjaan osmotik untuk mempertahankan kesetimbangannya.

Apa yang turut bekerja dalam pengaturan osmoregulasi dari moluska serta eksresi dari golongan invertebrate ini? Ginjal, sistim respirasi serta organ mantel yang berperan penting dalam pengaturan osmoregulasi. Kadang-kadang dalam mempertahankan osmoregulasi organisme ini menyerap nutrient dan garam untuk mempertahankan keseimbangan osmotik.

Spesis moluska yang lain yaitu cyclophorida, mereka hampir sama dengan golongan siput air tawar akan tetapi dapat juga hidup di darat. Golongan ini dapat dijumpai baik pada perairan tawar maupun di hutan yang memiliki kelembaban yang tinggi.

Budidaya laut merupakan suatu usaha yang besar, diantaranya adalah usaha budidaya kerang dan sejenisnya. Untuk menjauhkan permasalahan stress akibat tekanan osmotik, maka digunakan beberapa strategi untuk memastikan pengaturan terhadap osmoregulasi tidak menjadi masalah. Teknik ini sangat penting untuk keberlangsungan usaha budidaya kerang (Gross et al., 2001).

\section{OSMOREGULASI PADA GOLONGAN INVERTEBRATA}

Invertebrata laut pada umumnya isotonik terhadap lingkungan mereka dan merupakan osmoconformer (10.17). Mereka tidak memiliki mekanisme yang khusus untuk memindahkan air, tetapi mereka mengatur kandungan garamnya sehingga berbeda dengan kandungan air laut. Mereka memiliki pompa seluler dan beberapa impermeable terhadap garam. Spesis yang diam di tepi pantai serta estuari mengatur keseimbangan air. Beberapa menyerap air lebih ketika air laut mengencer, bahkan ada yang menambah ukuran selnya untuk mempertahankan keadaan isotonik (Oglesby, 1981).

Biasanya dengan difusi secara sederhana melalui pembuangan gas-gas. Pembuangan bahan nitrogen serta bahan lainnya adalah secara fagositosis melalui coelomocyt untuk dibawa ke tempat pembuangan (misalnya pada asteroida, bahan buangan dibawa ke papulae dimana melalui cara fagositosis dan kemudian dibuang melalui dinding popular). Kebanyakan ekinodermata adalah termasuk ke dalam golongan organisme laut dan osmokonformer, walaupun ada beberapa termasuk mendiami daerah payau.

\section{DAFTAR PUSTAKA}

Anonym, 1999. Canadian Council of Ministers of the Environment. 1999. Canadian water quality guidelines for the protection of aquatic life: Salinity (marine). In: Canadian environmental quality guidelines, 1999, Canadian Council of Ministers of the Environment, Winnipeg.

Bruijs M.C.M, Kelleher B., Van Der Velde G., de Vaate A.B., 2001. Oxygen consumption, temperature and salinity tolerance of the invasive amphipod 
Dikerogammarus villosus: Indicators of further dispersal via ballast water transport. Archives of Hydrobiology 152:633-646.

Gross W.J., Lasiewski R.C., Dennis M., and Rudy, P. Jr., 1966. Salt and water balance in selected crabs of Madagascar. Comp. Biochem. Physiol 17:660

Gross C., De Zeeuw J. and Simpao T., 2001. Awesome osmosis. Marine Discovery, University of Arizona.

Karnaky Jr. and Karl, J., 1998. "Osmotic and Ionic Regulation." In The Physiology of Fishes. $2^{\text {nd }}$ ed. Boca Raton: CRC Press.

Lockwood A.P.M., 1976. Physiological adaptations to life in estuaries. In: Newell RC (ed) Adaptation to Environment Essays on the Physiology of Marine Animals. Butterworths, London.

Nicol, J.A.C., 1967. The biology of marine animals. 2d ed. Wiley-Interscience, New York.

Oglesby L.C., 1981. Volume regulation in aquatic invertebrates. J Exp. Zool. 215:289-301. Pequeux, A. 1995. Osmotic regulation in crustaceans. J. Crust. Biol, 15:1-60.

Russell, J. M. 2000. Sodium-potassium-chloride cotransport. Physiol. Rev, 80:211276

Santagata S., Gasiūnaite Z.R., Verling E., Cordell J.R., Eason K., Cohen J.S., Bacela K., Quilez-Badia G., Johengen T.H., Reid D.F. and Ruiz G.M., 2008. Effect of osmotic shock as a management strategy to reduce transfers of nonindigenous species among low-salinity ports by ships. Aquatic Invasions, Vol. 3, No.1: 61-76.

Wittmann K.J and Ariani A.P., 2000. Limnomysis benedeni Czerniavsky: a Pontocaspian mysid new for the freshwaters of France (Crustacea, Mysidacea). Vie et Milieu 50: 117-122.

10.17. http://www.vattenkikaren.gu.se/fakta/arter/polychae/hedidive/hedidie.html 